\title{
A novel model of distal colon cancer in athymic mice ${ }^{1}$
}

\section{Novo modelo de câncer de cólon distal em camundongos atímicos}

\author{
Denise Gonçalves Priolli', Ana Margarida Abrantes ${ }^{\text {II }}$, Silvia Neves", Joana Neves Batista ${ }^{\text {III }}$, Izilda Aparecida Cardinalli" ${ }^{\text {IV }}$, Maria \\ Filomena Botelhov

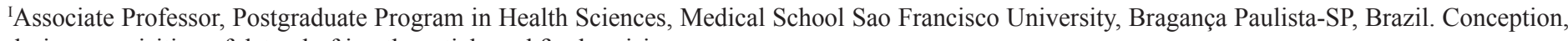 \\ design, acquisition of data; drafting the article and final revision.

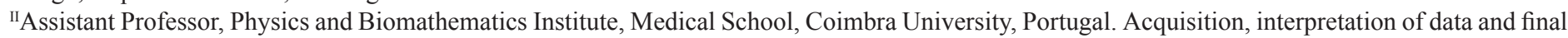 \\ revision. \\ IIIGraduate student, Physics and Biomathematics Institute, Coimbra University, Portugal. Acquisition and interpretation of data.

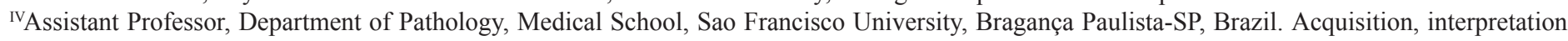 \\ of data and final revision. \\ ${ }^{\mathrm{v}}$ Chairwoman, Physics and Biomathematics Institute, Coimbra University, Portugal. Conception, design and critical revision.
}

\section{ABSTRACT}

PURPOSE: The present a novel adenocarcinoma model in athymic mice.

METHODS: Seven athymic mice were used. Colon diversion and distal fistula were made. Adenocarcinoma cells were inoculated in the submucosa of fistula. Tumor growth was monitored daily. Scintigraphy with 99mTc-MIBI was performed to identify the tumor.

RESULTS: The model of distal colon cancer is feasible. Tumor detection was possible by both, macroscopically and molecular imaging. All resections demonstrated poorly differentiated tumors. Colon obstruction occurred in one case, similarly to evolution in human tumors of distal colon.

CONCLUSION: The proposed model of distal colon cancer is feasible, allows for easy monitoring of tumoral growth by both, macroscopically and molecular imaging, and is suitable for studying the evolution of tumor with implementation of cytotoxic therapy in vivo.

Key words: Xenograft Model Antitumor Assays, Colorectal Neoplasms. Radionuclide Imaging. Technetium Tc 99m Sestamibi. Mice, Nude.

\section{RESUMO}

OBJETIVO: Apresentar novo modelo de adenocarcinoma distal em camundongos atímicos.

MÉTODOS: Foram utilizados sete camundongos atímicos. Desvio do cólon distal e fístula foram feitas. Células de adenocarcinoma foram inoculadas na submucosa da fístula. O crescimento do tumor foi monitorado diariamente. Cintilografia com 99mTc-MIBI foi realizada para identificar o tumor.

RESULTADOS: O modelo de câncer de cólon distal é viável. Detecção do tumor foi possível macroscopicamente e por imagem molecular. Todas as ressecções demonstraram tumores pouco diferenciados. Obstrução do cólon ocorreu em um caso, de forma semelhante à evolução em tumores humanos do cólon distal.

CONCLUSÃO: O modelo de câncer do cólon distal proposto é viável, permite a monitorização fácil do crescimento tumoral macroscopicamente e por imagem molecular, sendo adequado para o estudo da evolução de tumor com aplicação de terapia citotóxica in vivo.

Descritores: Ensaios Antitumorais Modelo de Xenoenxertos. Neoplasias Colorretais. Cintilografia. Tecnécio Tc 99m Sestamibi. Camundongos Nus. 


\section{Introduction}

A great deal of what we know about human biology is derived from animal studies. In some cases, such as study of cancer, is only possible to carry out studies using animal models. Better understanding of the mechanisms regulating the development, progression, and spread of colorectal tumors are required to obtain adequate animal models.

The introduction of athymic mice in the " 60 s was followed by great possibilities in research of implantable tumor models ${ }^{1,2}$. Understanding these models, accepting their limitations and improving its features are important and necessary for research development. These models offer not only increase understanding about the mechanism involved in pathogenesis, but also enable the development of anticancer therapies.

Currently, the most widely used animal model in cancer research is the athymic mouse. This use is mainly due to ideal characteristics, which include rapid tumor growth, easy handling, and the ability to accept human cells. Athymic mice have been used as an important biomedical tool ${ }^{1,2,3-10}$. Athymic mice accept xenogeneic and allogeneic grafts, including those of malignant tumors, because they are immunocompromised. Malignant tumor transplantation in athymic mice has been widely used in many type of cancer research, because the animal can maintain the original histological features of the tumor such as karyotype, expression of oncogenes, molecular structure and clonal evolution ${ }^{3}$. However, there is concern about the interaction between the tumor and the microenvironment. This issue not will be solved with the continued use of xenograft models, particularly heterotopic type.

Subcutaneous inoculation models can easily be established and is convenient for tumor observation. However, this site does not represent the local conditions of tumor origin. Tumors implanted subcutaneously produce solid masses, which are viewable, capable of being measured externally, and provide easy access for biopsy. The area usually has abundant vascularization and lymphatic drainage can be easily established, skin mobility allows large tumor expansion. The subcutaneous tumor model has a high tumor take rate and provides information about primary tumor response. Disadvantages of heterotopic xenografts are tumor growth encapsulated by connective tissue simulating benign tumor development; rarely express invasive or metastatic phenotypes, so their behaviors are quite different to what is seen clinically in humans ${ }^{5}$, maybe because a distinct microenvironment of tumor origin site.

Some orthotopic models are established in the literature, such as orthotopic models of breast ${ }^{4}$ and prostate ${ }^{5}$ cancer. An ideal colorectal cancer animal model should meet the biological characteristics and behaviors similar to those of human tumors, especially the tumor origin site. Realistic models of colorectal cancer are necessary to study cancer biology and evaluate therapeutic interventions. Currently, it is the most accurate orthotopic representation of human colon cancer is via a cecal injection 6,7,8,9. However, real-time observation and repeated sampling of implanted tumor is difficult to achieve in those model. This disadvantage was solved in 2009 with cecostomy model ${ }^{8}$.

Although the incidence is modifying, most colorectal cancers arise in the distal colon, so, a distal colon cancer models is desirable. Thus, the aim of this study was to present a novel model of cancer in distal colon that allows a real-time observation and could be suitable for studying the tumor evolution with implementation of cytotoxic therapy, by macroscopy, microscopy and scintigraphic detection, in vivo.

\section{Methods}

In this study were used eight-week old mice (Balb/c nu/ nu) from Charles River, Spain.

Animals were fasted for 12 hours. On the day of surgery, mice were weighed and anesthetized with chlorpromazine plus ketamine, diluted $1: 3(0.1 \mathrm{ml} / 20 \mathrm{~g})$ and administered subcutaneously. The abdomen was sterilized with $0.2 \%$ iodine tincture, after being completely anesthetized. All procedures were performed with a $3 \mathrm{X}$ magnifying lens and done under sterile conditions.

This study follows the Declaration of Helsinki, Portuguese Society of Animal Science Laboratory (SPCAL) guidelines ${ }^{10}$ in accordance with Council for International Organization of Medical Sciences (CIOMS) Ethical Code for Animal Experimentation and Ethical Committee of Coimbra University (protocol number: 3-CE-2011).

\section{Procedures}

\section{$\underline{\text { Tumor cell culture }}$}

WiDR colorectal adenocarcinoma cell line (CCL-218from American Type Culture Collection (ATCC)) was used in this study. The cell line was thawed and propagated in culture at $37^{\circ} \mathrm{C}$ in a humidified chamber with $5 \% \mathrm{CO}_{2}$ (HeraCELL 150) using Dulbecco's Modified Eagle Medium (DMEM - Sigma D-5648), supplemented with $100 \mu \mathrm{M}$ sodium pyruvate (Gibco-11-360), $10 \%$ fetal bovine serum (Gibco 2010-09) and 1\% antibiotic (100 $\mathrm{U} / \mathrm{ml}$ penicillin and $10 \mu \mathrm{g} / \mathrm{mL}$ streptomycin, Gibco 15140-122).

The tumor cell cultures were incubated with $3 \mathrm{~mL}$ of 
Trypsin-EDTA, 0.25\% (Gibco 25 200), for three minutes to allow cell separation. The culture medium was changed every 24 hours.

The viability of the cells were determined using a Neubauer chamber and were evaluated by the exclusion of Trypan blue.

\section{Surgical technique}

Colon diversion was performed with a proximal colostomy and distal fistula. First, the abdominal cavity was opened (Figure 1).

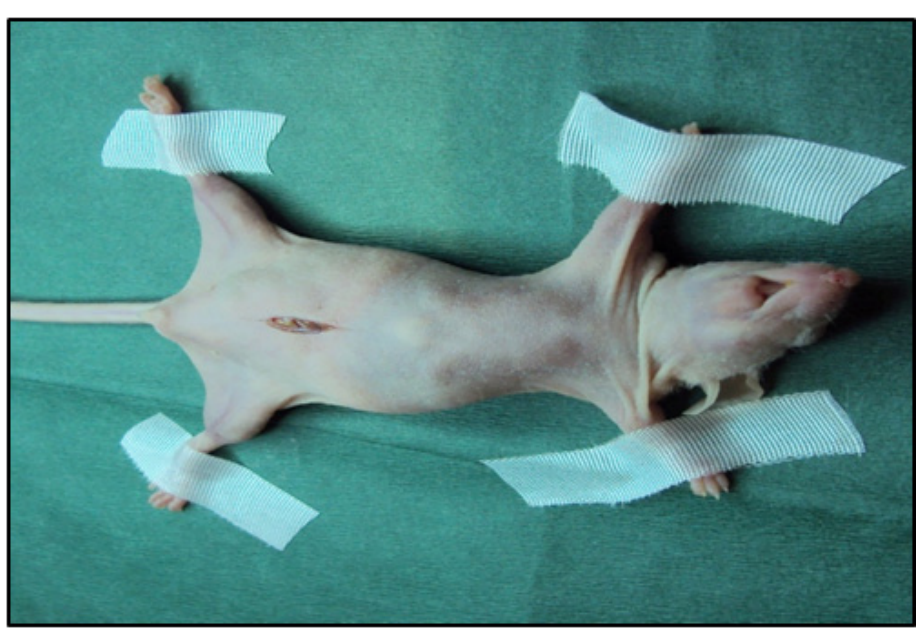

FIGURE 1 - Surgical technique. Abdomen was opened.

Then, two openings ( $2 \mathrm{~mm}$ in length) were created in the left iliac region, all layers, lying about $10 \mathrm{~mm}$ from each other, in the craniocaudal line. The distal colon was identified. A colon section was made $20 \mathrm{~mm}$ from the peritoneal reflection between mesentery vessels. The stoma was fixed to the wall by simple suture (Figure 2) to the edge of the incision in a circumferential manner located at the cardinal points using a 7-0 polypropylene thread and needle (cylindrical $8 \mathrm{~mm}$ circular 220 microns).

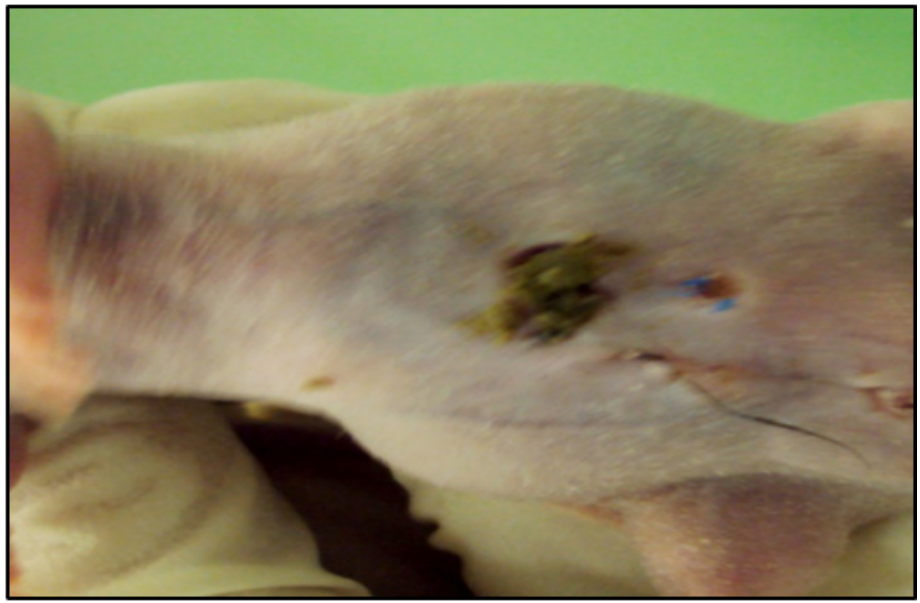

FIGURE 2- Surgical technique. Colon diversion and distal fistula was performed.
Abdominal wall was closed in layers, aponeurosis and skin, with 6-0 cotton thread, $7 \mathrm{~mm}$ needle, triangular.

\section{Tumor cell inoculation}

Seven days after surgery, the tumor cells were suspended in $40 \mu \mathrm{l}$ of normal saline and $4 \mathrm{X} 10^{6}$ cells were directly seeded into the submucosa of fistula using a $1 \mathrm{ml}$ syringe with a hypodermic 30-gauge needle.

\section{Postoperative time}

After the operation, animals were housed in individual cage. After fully awaking from surgery, they were subjected to standard water and chow until the time of death. Animals were monitored after inoculation daily.

\section{Imaging with 99mTc-methoxyisobutylisonitrile (MIBI)}

Animals were anesthetized as previous described.

MIBI injection was performed in the dorsal tail vein. Immediately after, acquisitions with a dynamic gamma camera (GE 400 AC) were started. The computer software GenieAcq controlled acquisition and it was made in two sequential phases. During the dynamic phase, images were taken every 30 seconds for five minutes. Then, static images were obtained at 10, 30, 60, and 90 minutes. These images were acquired and then processed by Xeleris workstation.

\section{Histopathologic analysis}

Tumor resection was performed. The excised specimen was fixed in formaldehyde, embedded in paraffin block and subjected to longitudinal sections. The slides were then stained with hematoxylin-eosin. The presence and degree of differentiation of tumor were determined.

\section{Results}

Tumor was grown in three of seven animals seeded. Four days after cell inoculation, tumor vision was macroscopically possible. The day after, tumor detection was possible by molecular imaging with MIBI. Tumors were identified as areas with increased uptake at 10 minutes after radiopharmaceutical injection (Figure 3). 


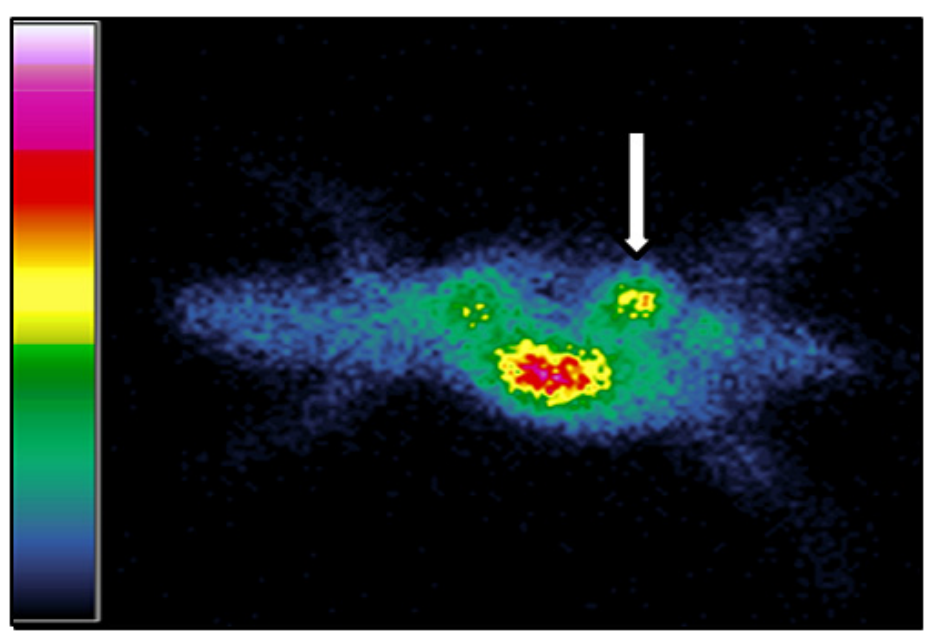

FIGURE 3 - Scintigraphy. Area with increased uptake was showed after MIBI injection.

Histopathological examination revealed clusters of large cells with an acidophilic cytoplasm and nuclei that were large and oval or round, vacuoles, prominent and central nucleoli, and delicate chromatin, poorly differentiated tumors (Figure 4).

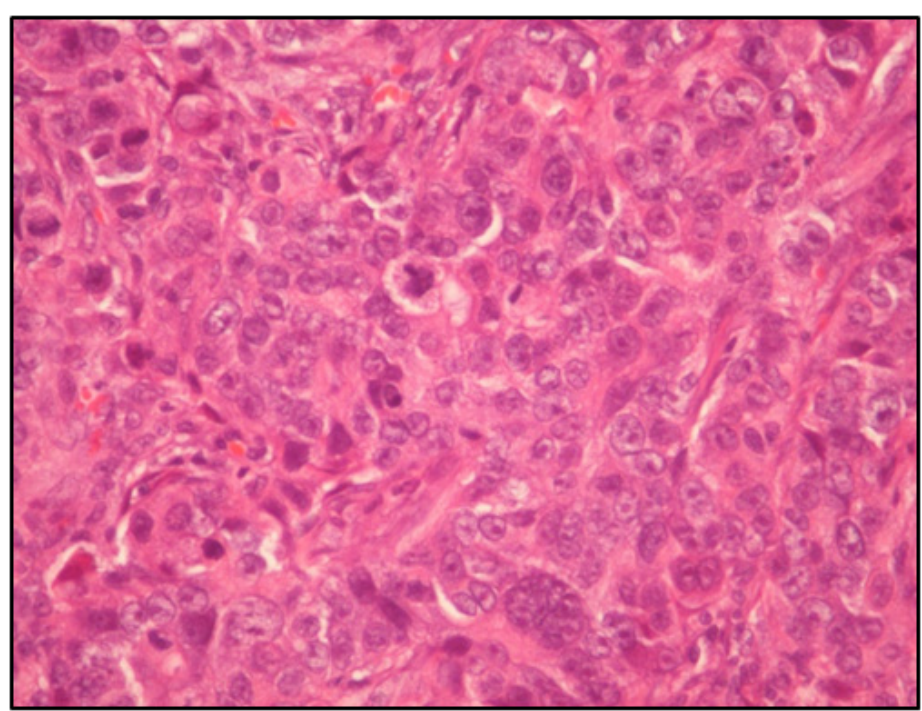

FIGURE 4 - Histopathology. Poorly differentiated tumor was demonstrated (HE- 400x).

All tumors presented ulcerative growing. In one case has occurred colon obstruction 21 days after tumor cells inoculation. Metastasis was not found.

\section{Discussion}

To gain confidence in the validity of research using the animal model, clear and convincing data are needed. Furthermore, disease models need to be continually adapted to reflect the therapeutic environment necessary for research. The development of models not only helps our understanding of biological processes in tumor development, but also allow for the development of new therapies based on signaling cascades, growth factors, and angiogenesis factors. Individualized therapy is strongly dependent on scientific interpretation of relevant clinical parameters. Thus, an animal model that is most similar to humans is required so that we can validate results.

In 2007, orthotopic colon cancer model was described in which tumor cells were inoculated in the cecal wall of animal ${ }^{7}$. That model proved to be a significant advancement in colon cancer model. However, monitoring the evolution of these tumors is affected because of the intracavitary nature of the model. To improve this model, in 2009, a cecostomy implantation was proposed $^{8}$. In those models, with or without colon diversion, cell was inoculated in cecum, less frequent location for colon adenocarcinoma, which is more prevalent in the distal colon, although this incidence is changing. Distincts embryological origins are reflected in different anatomical aspects when considering arterial blood supply, venous drainage, lymphatic and innervations of each of the colon segments ${ }^{11}$. Likewise, physiological and metabolic functions from each segment of the colon also differ, suggesting that, in reality, the colon consists in two separate bodies that are arranged in continuity ${ }^{12}$. Recent genetic studies using microarray-based techniques have demonstrated that the gene expression profiles of the proximal and distal colon differ. This suggests that distinct responses of these genes are likely under the action of intraluminal carcinogens ${ }^{13,14}$. It is possible that different responses to therapeutic are related to distinct carcinogenesis pathway between distal or proximal tumors. It is well known that the carcinogenesis process for tumors located in distal colon is related to the adenoma-carcinoma sequence in which mutation of p53 gene is a common event. In the other hand, tumors located in the proximal colon are considered as "de novo" cancer, and are generally associated with mutation in repair proteins ${ }^{13}$. These differences, well known, make more desirable the development of cancer model for distal colon. Thus, if the research requires results about distal colon, the inoculating of tumor cells in the cecal wall, would be creating a new heterotopic model. The cecum model is not a desirable orthotopic model that can allow the comparative extrapolation between all human tumors or, at least, with the distal human tumor. To understand the mechanisms regulating the colon carcinogenesis and to propose therapeutics that is more adequate, both models of colon adenocarcinoma, distal and proximal, are necessary, but it have be analyzed specifically.

Few studies have used orthotopic model in distal colon $^{15,16,17}$. Tumor measurement and tumor tissue collection are neither easy nor accurate, consequently, this model is seldom used. 
In this study, the tumor implanted at the fistula demonstrated the same characteristics seen in human colonic carcinomas. Tumor development occurred in submucosa, resembling their spontaneous development and histopathologic examination revealed poorly differentiated tumor identically to tumor cells inoculated. In one case, colon obstruction occurred 21 days after neoplastic cell inoculation, as sometimes occurs in distal human tumor. Additional care should be taken when performing the derivation, increasing the distance between colostomy and mucous fistula in order to avoid this complication and allow more time of observation, especially when the development of metastasis is desirable. Metastasis was not found in this study, probably because the time had been insufficient to spread of tumor cells or insufficient number of cell has been seeded. Another possibility would be the genotypic feature of tumor cell as invasiveness and metastatic potential.

Images performed with MIBI showed tumor, at 10 minutes after radiopharmaceutical injection, in agreement with the results of another research ${ }^{18}$. The MIBI has been suggested as a marker for scintigraphic detection of drug resistance ${ }^{17}$. It is also a radiotracer for the detection of primary or secondary tumors and has value in planning prophylactic therapy for metastases ${ }^{19}$ as well as allows for the monitoring of tumor cell viability after radiotherapy ${ }^{20}$. In this model, the possibility of tumor detection by molecular imaging allows not only the monitoring of evolution of its growth, but also the observation of therapeutic response in real time. Thus, it is extremely important that the model allow for marking with this radiopharmaceutical, not only to detect the lesion, but also to guarantee the monitoring of response to anticancer therapies in future researches.

The main advantages of animal model presented here are: model can be established in distal colon; tumor growth can be easily visualized and measured by molecular imaging in vivo, which makes evaluation of tumor response to interventions much easier; repeated sampling of the tumor tissue for pathological examinations is feasible. Additional advantage of this model is enable comparative studies about influence of microenvironment in tumor development in distal or proximal colon.

The present study showed a more accurate model of distal cancer of colon that allows the follow up of tumor in real time. This model could offer understanding of interactions between the tumors with its original microenvironment, increasing the understanding about the mechanism involved in pathogenesis bringing also the opportunity to the development of specific therapies to distal colon cancer.

\section{Conclusion}

Orthotopic model of distal colon is feasible, allows monitoring the tumoral growth by molecular imaging and is suitable for studying the evolution with implementation of cytotoxic therapy in real time.

\section{References}

1. Pantelouris EM. Absence of thymus in a mouse mutant. Nature. 1969;217(5126):370-1.

2. Rygaard J, Polvsen CO. Heterotransplantation of a malignant tumour to "Nude" mice. Acta Pathol Microbiol Scand. 1969;77(4):758-60.

3. Rygaard K, Sorenson GD, Pettengill OS, Cate CC, Spang-Thomsen M. Abnormalities in structure and expression of the retinoblastoma gene in small cell lung cancer cell lines and xenografts in nude mice. Cancer Res. 1990;50(17):5312-7.

4. McManus MJ, Dembroske SE, Pienkowski MM, Anderson TJ, Mann LC, Schuster JS, Vollwiler LL, Weisch CU. Successful transplantation of human benign breast tumors into the athymic nude mouse and demonstration of enhanced DNA synthesis by human placental lactogen. Cancer Res. 1978;38(8):2343-9.

5. Stephenson RA, Dinney CP, Gohji K, Ordóñez NG, Killion JJ, Fidler IJ. Metastatic model for human prostate cancer using orthotopic implantation in nude mice. Natl Cancer Inst. 1992;84(12):951-7.

6. Fidler IJ. Orthotopic implantation of human colon carcinomas into nude mice provides a valuable model for the biology and therapy of metastasis. Cancer Metastasis Rev. 1991;10(3):229-3.

7. Céspedes MV, Espina C, García-Cabezas MA, Trias M, Boluda A, Gómez del Pulgar MT, Sancho FJ, Nistal M, Lacal JC, Mangues R. Orthotopic microinjection of human colon cancer cells in nude mice induces tumor foci in all clinically relevant metastatic sites. Am J Pathol. 2007;170(3):1077-85.

8. Jin H, Liu X, Li VK, Ding Y, Yun S, Liu F, Zhou S, Song Y, Ni M. A simple colostomy implantation model for evaluating colon cancer. Int J Colorectal Dis. 2009;24:41-7.

9. Hwang JE, Shim HJ, Park YK, Cho SH, Bae WK, Kim DE, Kim KK, Chung IJ. Intravenous KITENIN shRNA injection suppresses hepatic metastasis and recurrence of colon cancer in an orthotopic mouse model. J Korean Med Sci. 2011;26(11):1439-45.

10. SPCAL. Sociedade Portuguesa de Ciências em Animais de Laboratório. Saúde [cited 2009 nov] Available from http://www. spcal.pt

11. Bufill JA. Colorectal cancer: evidence for distinct genetic categories based on proximal or distal tumor location. Ann Intern Med. 1990;113(10):779-88.

12. Gervaz P, Bouzourene H, Cerottini JP, Chaubert P, Benhattar J, Secic M, Wexner S, Givel JC, Belin B. Dukes B colorectal cancer: distinct genetic categories and clinical outcome based on proximal or distal tumor location. Dis Colon Rectum. 2001;44(3):364-72.

13. Glebov OK, Rodriguez LM, Nakahara K, Jenkins J, Cliatt J, Humbyrd CJ, DeNobile J, Soballe P, Simon R, Wright G, Lynch P, Patterson S, Lynch H, Gallinger S, Buchbinder A, Gordon G, Hawk E, Kirsch IR. Distinguishing right from left colon by the pattern of gene expression. Cancer Epidemiol Biomarkers Prev. 2003;12(8):755-62.

14. Martinez CAR, Priolli DG, Cardinalli IA, Pereira JA, Portes AV, Margarido NF. Influencia da localização do tumor na expressão tecidual da proteína p53 em doentes com câncer colorretal. Estudo de 100 casos. Rev Col Bras Cir. 2008;35(4):235-43. 
15. Kashtan H, Rabau M, Mullen JB, Wong AH, Roder JC, Shpitz B, Stern HS, Gallinger S. Intra-rectal injection of tumor cell: a novel animal model of rectal cancer. Surg Oncol. 1992;1(3):251-6.

16. Chen Y, Chang KJ, Hwang LH, Chen CN, Tseng SH. Establishment and characterization of a rectal cancer model in mice: application to cytokine gene therapy. Int J Colorectal Dis. 2002;17:388-95.

17. Donigan M, Loh BD, Norcross LS, Li S, Williamson PR, DeJesus S, Ferrara A, Gallagher JT, Baker CH. A metastatic colon cancer model using nonoperative transanal rectal injection. Surg Endosc. 2010;24(3):642-7.

18. Lorke DE, Krüger M, Buchert R, Bohuslavizki KH, Clausen M, Schumacher U. In vitro and in vivo tracer characteristics of an established multidrug-resistant human colon cancer cell line. J Nucl Med. 2001;42(4):646-54.

19. Wakasugi S, Noguti A, Katuda T, Hashizume T, Hasegawa $Y$. Potential of $(99 \mathrm{~m}) \mathrm{Tc}-\mathrm{MIBI}$ for detecting bone marrow metastases. J Nucl Med. 2002;43(5):596-602.

20. Zhu X, Wu H, Xia J, Zhao M, Xianyu Z. The relationship between $(99 \mathrm{~m}) \mathrm{Tc}-\mathrm{MIBI}$ uptakes and tumor cell death/proliferation state under irradiation. Cancer Lett. 2002;182(2):217-22.

\section{Correspondence:}

Denise Gonçalves Priolli

Rua São Vicente, 614

12947-390 Atibaia - SP Brasil

Tel./Fax: (55 11)4412-7730

depriolli@terra.com.br

Received: January 18, 2012

Review: March 14, 2012

Accepted: April 16, 2012

Conflict of interest: none

Financial source: Sao Paulo Research Foundation (FAPESP)

${ }^{1}$ Research performed at Institute of Biomedical Research on Light and Image (IBILI), Physics and Biomathematics Department, Coimbra University, Portugal and Sao Francisco University, Postgraduate Program in Health Sciences, Bragança Paulista-SP, Brazil. 